\title{
Attempt to Cross-Foster Gray Wolf, Canis lupus, Pups into Another Wolf Pack
}

\author{
Ronald N. Schultz ${ }^{1}$, Adrian P. WydeVen ${ }^{2}$, Linda S. WinN ${ }^{1}$, and Sheri A. Buller ${ }^{1}$ \\ ${ }^{1}$ Wisconsin Department of Natural Resources, 8770 Highway J, Woodruff, Wisconsin 54568 USA \\ ${ }^{2}$ Wisconsin Department of Natural Resources, 875 South $4^{\text {th }}$ Avenue, Park Falls, Wisconsin 54552 USA
}

Schultz, Ronald N., Adrian P. Wydeven, Linda S. Winn, and Sheri A. Buller. 2007. Attempt to cross-foster Gray Wolf, Canis lupus, pups into another wolf pack. Canadian Field-Naturalist 121(4): 430-432.

We attempted to cross-foster four 18-19 week-old Gray Wolf (Canis lupus) pups into another Wolf pack $182 \mathrm{~km}$ from their natal pack territory. The pup introduction was the result of depredation control on a farm in northwestern Wisconsin. Three pups died within 14 days of release. A fourth pup survived along the edge of the new pack territory over winter, dispersed in the spring, joined or formed a new pack and was captured on a depredation complaint four years later.

Key Words: Gray Wolf, Canis lupus, introduce, depredation, natal pack, Wisconsin.

Depredation control programs on Gray Wolves, (Canis lupus) may create concern about how to humanely deal with wolf pups captured at depredation sites. Such problems can be especially acute when lethal controls are not allowed.

It has been demonstrated that Black Bear (Ursus americanus) cubs have been successfully introduced to other female bears (Carney 1985). Cross-fostering of week-old captive Coyote (Canis latrans) pups was highly successful (Kitchen and Knowlton 2006). Crossfostering has been successful in captive Red Wolves (Canis rufus) with all fostered wolves surviving to weaning (Waddell et al. 2002*), and has been successful for captive Gray Wolves (Canis lupus) (Goodman 1990). Two captive-born Red Wolf pups were fostered into a wild wolf den containing two pups of identical age in 2002 (U. S. Fish and Wildlife Service 2004 Fostered red wolf recaptured and released. Red Wolf News 5: 2, US Fish and Wildlife Service, Manteo, North Carolina, Unpublished report). Two 6-month-old pups that were given standard soft releases in separate translocation incidents remained cohesive with adult pack members after release and survived (Bradley et al. 2005). In Wisconsin a wolf pup was successfully reintroduced back into its natal pack after 53 days in captivity (Schultz et al. 1999).

However, not all cross-fostering pup translocation attempts have been successful. An attempt was made to cross-foster six 3 to 4-week-old Mexican wild wolf pups (Canis lupus baileyi) to a surrogate adult pair at the Sevilleta National Wildlife Refuge Mexican Wolf Management Facility that had two pups, but they were rejected and killed by the adult male (Mexican Blue Range Reintroduction Project Monthly Update 1-31 May 2006. Unpublished report). Two hard release translocation events, including three 5-month-old pups in northwestern Montana resulted in abandonment by adult members after release, and the pups died soon thereafter (Bradley et al. 2005).

To our knowledge there have never been any attempts made to cross-foster 18 to 19 -week-old weaned free rang- ing wild Gray Wolf pups into another wild wolf pack. We describe an experimental cross-fostering of wild post-weaning Gray Wolf pups at an age before they began accompanying adults on hunts (Mech 1970) into another pack territory in Wisconsin during a time when translocations were used to deal with problem wolves.

\section{Methods}

Four 13 to 14-week-old Gray Wolf pups, two females (F390, F393) and two males (M391, M392) were captured on a farm in northwest Wisconsin where cattle were being killed by wolves. Wolf M392 was captured on 25 July, M391 on 27 July, F390 on 30 July, and F393 on 31 July 2001. A lactating adult female, F367 was previously caught on this farm on 26 May 2001, and released with a shock collar (Schultz et al. 2005) $5.3 \mathrm{~km}$ from the farm because she was likely nursing a litter of pups. Three other wolves (one yearling male, one adult male, one adult female) were also captured at the farm in August and were translocated $260 \mathrm{~km}$ from the farm. In previous years, two different wolf packs bordered the farm: the River Side Pack to the east and Chases Brook pack to the north and west. We were unable to determine which pack the pups came from and were concerned the pups might be abandoned if translocated with the adults, so they were transported to a holding pen $174.8 \mathrm{~km}$ from their capture site.

The holding pen consisted of a $3 \mathrm{~m} 2$ enclosure with an artificial den $(46 \times 81 \times 61 \mathrm{~cm})$ placed $0.3 \mathrm{~km}$ from the nearest human dwelling. The four pups were fed a mixture of $60 \%$ venison, $40 \%$ dry dog food (Tuffy's, Division of H. J. Heinz, Perham, Minnesota 56573, USA). All four pups were given a $0.5 \mathrm{ml}$ injection of Gentocin (Schering-Plough Animal Health Corp. Kenilworth, New Jersey 07033) daily for 21 days to treat trap-related injuries.

On 16 August 2001, a White-tailed Deer (Odocoileus virginianus) carcass was placed by a rendezvous site commonly used by the Bootjack Lake Pack (BJLP). On 20 July 2001 pups and adult wolves responded on a howling survey from the rendezvous 


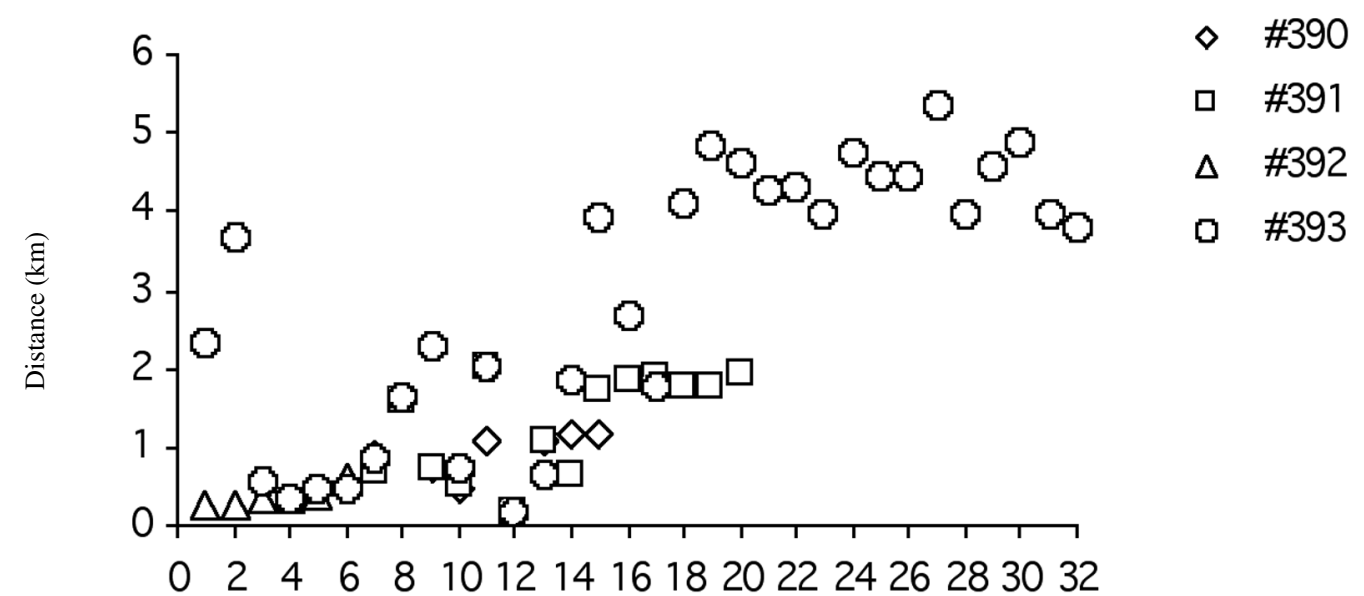

Days after release from holding pen

FIGURE 1. Daily distance pups F390, M391, M392 and F393 moved from holding pen, (28 August to 29 September 2001).

site and on 21 July 2001 an industrial forest employee saw one gray and three black wolf pups $200 \mathrm{~m}$ southeast of the rendezvous site.

On 19 August 2001 a new holding pen of the same size was erected $30 \mathrm{~m}$ from the deer carcass drop site, next to the rendezvous site. On 20 August 2001 all four pups were weighed $(10.9-11.8 \mathrm{~kg})$ and fitted with radio tracking collars (Telonics Inc., Mesa, Arizona 85204-6699 USA). The radio collars were lined with Rockford 3319 foam rubber (Rockford Supply Inc. 1500 Washington Avenue, North Minneapolis, Minnesota 55411) to compensate for neck growth. The four pups were then transported to the new holding pen, and another deer carcass was dropped off. Three adult wolves from the BJLP spontaneously howled while the pups were being placed in the new pen.

On 28 August 2001, all four pups were given a 1-ml external treatment of Revolution (Pfizer Animal Health Exton, Pennsylvania 19341, USA, Division of Pfizer Inc., New York 10017) and 0.5-ml subcutaneous injection of Ivermectin (MSD-AGVET, Division of Merck \& Co., Rahway, New Jersey 107065, USA) to kill a heavy infestation of lice (Trichodectes canis).

Wolves F393 and M392 were released from the holding pen on 28 August 2001, and wolves F390 and M391 were released on 3 September 2001. Venison and dry dog food were placed in the holding pen every day for the next five days. Deer carcasses were dropped off every 2-3 days for the next 17 days. All pups were located one or more times daily for the first 32 days after release and one or more times weekly thereafter.

Necropsies on all pups that died were performed by wildlife disease specialists and pathologists at the United States Geological Survey (USGS) National Wildlife Health Center in Madison, Wisconsin.

\section{Results}

The pups repeatedly returned to feed on the deer carcasses and remained within $4.0 \mathrm{~km}$ of the release site for the first 14 days (Figure 1). Adult wolf tracks were observed at the deer carcasses on 5 and 8 September 2001, and on 9 September 2001 an adult wolf was observed by the deer carcass drop site, confirming members of the BJLP were visiting the site.

On 3 September 2001, wolf M392 was found dead $0.4 \mathrm{~km}$ from the holding pen. The body was partially submerged in water on the edge of a small marsh. His carcass looked to be in good condition, did not have any external wounds, and had gained $1.5 \mathrm{~kg}$ from when he was collared. Necropsy results revealed congested lungs, and death probably due to bacterial pneumonia (USGS, National Wildlife Health Center, Case 17366). On 12 September 2001, wolf F390 was found dead $1.1 \mathrm{~km}$ from the holding pen at the edge of a northern White Cedar (Thuja occidentalis) swamp. F390 had deep puncture wounds to the head and throat, and a fractured skull and ribs. F390 had gained $2.4 \mathrm{~kg}$ from when she was collared (USGS, National Wildlife Center, Case 17394). Adult male wolf M336 of the BJLP was located at the same location as F390 on 10 September 2001, so it was assumed he or other pack members may have killed the pup.

On 17 September 2001, wolf M391 was found dead $1.9 \mathrm{~km}$ from the holding pen on an old Beaver (Castor canadensis) dam. M391 had superficial puncture wounds to the throat and lower jaw. The superficial wounds may have occurred on 10 September 2001 when M391 was located near F390 and M336. Necropsy results revealed congested lungs and death probably due to bacterial pneumonia (USGS, National 
Health Wildlife Center, Case 17395). M391 had gained $2.8 \mathrm{~kg}$ from when he was collared. The average weight gain of all three pups from release date until their deaths was $0.21 \mathrm{~kg}$ per day. This was double the standard weight gain of 17 wild-caught female wolf pups (Van Ballenberghe and Mech 1975).

Wolf pups F390, M391 and M392 stayed within $1.9 \mathrm{~km}$ of the release pen until their death. Wolf pup F393 moved $3.7 \mathrm{~km}$ from the release site two days after being released but returned 3 days later. She remained within $2.7 \mathrm{~km}$ of the release site until $15 \mathrm{Sep}-$ tember 2001, when she moved $4.1 \mathrm{~km}$ (figure 1) and stayed within a $3.5 \mathrm{~km} 2$ area until 4 December 2001. She then moved $23.2 \mathrm{~km}$ southwest of the holding pen. Pilots observed F393 with two other wolves on 8 January 2002 , but she did not appear to establish a new territory during the winter of 2002.

In spring 2002, wolf F393 dispersed westward and by summer had settled into the Long Lake Pack area $106 \mathrm{~km}$ southwest of the Bootjack Lake Pack. On 1 August 2005, wolf F393 was captured and euthanized on a depredation complaint. Five placental scars were observed on F393 necropsy, confirming she apparently raised pups in 2004 and 2005 (USGS, National Wildlife Health Center, Case 19680).

\section{Discussion}

The cross-fostering attempt was not successful, but one pup $(25 \%)$ of the four did survive and eventually joined up with other wolves. This pup remained alive, but abandoned the Bootjack Lake Pack's territory. None of the pups joined the new pack, and three died within 15 days of release. Two of the pups (50\%) had injuries which were assumed to have been inflicted by Wolves from the BJLP. The cross-fostering attempt might have been more successful if the pups had been introduced to a pack adjacent to their natal pack's territory where there may have been some interaction between packs (Hamilton 1964). Perhaps if the pups had been placed in the BJLP's territory earlier and kept in the holding pen longer, the BJLP wolves would have become more bonded to them (Bradley et al. 2005). We also assume that pup mortality may be high on this type of introduction, as in bears, and should only be attempted under extreme circumstances.

\section{Acknowledgments}

Persons assisting in the capture and monitoring of the four wolf pups included Michael Weinfurter, Ed- ward Zwisik and Mathew Nilson. Wolf monitoring was funded by the Chequamegon Nation Forest, U.S. Fish and Wildlife Service, Section 6 Grant, Federal Aid in Wildlife Restoration Project W-145-R and Wisconsin Endangered Species Fund. Depredating wolves were captured by personnel of United States Department of Agricuture-APHIS-WildlifeServices under the direction of Robert Willging. A special thanks to Nancy Thomas, Valerie Shearn-Bochsler, and Grace McLaughlin at the USGS, National Wildlife Health Center Madison, Wisconsin for necropsy results. We also thank Ellen Heilhecker for literature research.

Document Cited (marked * in text)

Waddell, W., S. Behrns, C. Lucash, and S. Mclellan. 2002. Intraspecific fostering in the red wolf (Canis rufus). Poster at Carnivores 2002, Monterey, California.

\section{Literature Cited}

Bradley, E. H., D. H. Pletscher, E. E. Bangs, K. E. Kunkel, D. W. Smith, C. M. Mack, T. J. Meier, J. A. Fontaine, C. C. Niemeyer, and M. D. Jimenea. 2005. Evaluating wolf translocation as a non-lethal method to reduce livestock conflicts in the northwestern United States. Conservation Biology 19: 1498-1508.

Carney, D.W. 1985. Population dynamics and denning ecology of Black Bears in Shenandoah National Park, Virginia. Masters thesis, Virginia Polytechnic Institute and State University, Blacksburg, Virginia, USA.

Goodman, P. A. 1990. In: A history of wolf park 1972-1999. Ethology Series, volume 5. Institute of ethology, North American Wildlife Park Foundation, Battle Ground, Indiana.

Hamilton, W. D. 1964. The genetical evolution of social behavior. Journal of Theoretical Biology 7: 1-52.

Kitchen, A. M., and F. F. Knowlton. 2006. Cross-fostering in coyotes: evaluation of a potential conservation and research tool for canids. Biological Conservation 129: 221-225.

Mech, D. L. 1970. The wolf: the ecology and behavior of an endangered species. University of Minnesota Press, Minneapolis, USA. Pages 136, 140-143.

Schultz, R. N., K. W. Jonas, L. H. Skuldt, and A. P. Wydeven. 2005. Experimental use of dog-training shock collars to deter depredation by gray wolves. Wildlife Society Bulletin 33: 142-148 USA.

Schultz, R. N., A. P. Wydeven, and J. M. Stewart. 1999. Acceptance of a gray wolf, Canis lupus, pup by its natal pack after 53 days in captivity. The Canadian Field-Naturalist 113: 509-511.

Van Ballenberghe, V., and L. D. Mech. 1975. Weights, growth and survival of timber wolf pups in Minnesota. Journal of Mammalogy 56: 44-63.

Received 15 November 2006

Accepted 7 August 2008 